\title{
35. MID-ATLANTIC RIDGE COCCOLITH AND SILICOFLAGELLATE BIOSTRATIGRAPHY, DEEP SEA DRILLING PROJECT SITES 558 AND $563^{1}$
}

\author{
David Bukry, United States Geological Survey and Scripps Institution of Oceanography ${ }^{2}$
}

\begin{abstract}
Low-latitude coccolith zonation can be used for biostratigraphy at Mid-Atlantic Ridge sites DSDP 558 (lat. $38^{\circ} \mathrm{N}$ ) and DSDP 563 (lat. $34^{\circ} \mathrm{N}$ ). The low-latitude zonal sequence from lower Oligocene to Holocene is interrupted by coolwater assemblages in upper middle Miocene and by hiatuses that removed the lower Pliocene and part of the upper Pliocene. A gap in the range of zonal guide fossil Discoaster druggii in the lower Miocene, also identified in other ocean basins, occurs at both DSDP 558 and 563 . Coccoliths are abundant and moderately overgrown at both sites. Pentaliths occur in the Oligocene at DSDP 563 but are missing at DSDP 558, probably the result of diagenesis. New taxa of coccoliths identified include Cyclolithella? neoaprica Bukry, n. sp., and Sphenolithus calyculus Bukry, $\mathrm{n}$. sp.

Silicoflagellates are limited to the upper Quaternary at DSDP 558 with warm-water assemblages of the Dictyocha aculeata Zone and possibly the upper Mesocena quadrangula Zone, as indicated by the presence of Dictyocha lingii. A new silicoflagellate species, Distephanus floridus Bukry, n. sp., is described.
\end{abstract}

\section{INTRODUCTION}

Leg 82 of the Deep Sea Drilling Project cored nine sites in a small area on the west flank of the Mid-Atlantic Ridge, west and southwest of the Azores Triple Junction. Although the primary goal of Leg 82 was to study trace element geochemistry of different types of basalt, several long sedimentary reference sections were also cored at Sites DSDP 558 and DSDP 563. Coccoliths are especially abundant but moderately to thickly overgrown throughout and silicoflagellates are common only in the uppermost cores of DSDP 558. Biostratigraphic assignment for 200 samples from four sites of Leg 82 is based on Okada and Bukry (1980) for coccoliths and Bukry (1981a) for silicoflagellates. The coccolith zonal assignments of the cores are summarized (Table 1) and discussed. The mid-ocean assemblages of DSDP 558 are contrasted to those of DSDP 369, a site of coastal upwelling off northwestern Africa. The short upper Pleistocene silicoflagellate-bearing section of DSDP 558 is compared to other coeval assemblages from the Atlantic and Pacific. Two new species of coccoliths and one new silicoflagellate are described and illustrated.

Coccolith interpretations are based on light-microscope examination of smear-slide preparations, whereas silicoflagellate assemblages are enumerated from slides of acid-residue preparations.

\section{BIOSTRATIGRAPHY}

Site 558 (lat. $37^{\circ} 46.2^{\prime} \mathrm{N}$, long. $37^{\circ} 20.61^{\prime} \mathrm{W}$; water depth, $3754 \mathrm{~m}$ )

Site DSDP 558 is located on the west flank of the Mid-Atlantic Ridge about $50 \mathrm{~km}$ south of the Pico Frac-

\footnotetext{
${ }^{1}$ Bougault, H., Cande, S. C., et al., Init. Repts. DSDP, 82: Washington (U.S. Govt. Printing Office).

2 Address: United States Geological Survey (A-015), Scripps Institution of Oceanography, La Jolla, California 92093.
}

ture Zone, on the magnetically reversed interval between Anomalies 12 and 13 (approximately $35 \mathrm{Ma}$ ). The 408-m sedimentary section contains abundant coccoliths ranging from lower Oligocene (CP16b) to upper Quaternary (CN14/CN15). The lower Pliocene to uppermost Miocene interval is missing, or condensed and unrecovered, between upper Pliocene Subzone CN12a in Sample 558A-9-3, 90-91 cm and upper Miocene Subzone CN9b in Sample 558A-10-1, 90-91 cm.

First, Site 558 was rotary cored continuously from 158 to $415 \mathrm{~m}$ through the sedimentary section to basalt. This was followed by hydraulic piston coring to recover the complete upper sedimentary section from 0 to $132 \mathrm{~m}$ in Hole 558A. Coccolith biostratigraphy suggests a slight gap between the two holes in the interval of the upper Miocene Discoaster neorectus Subzone (CN8b).

The deepest sediment available from Sample 558-27-1, 90-91 cm (406 m) contains a typical lower Oligocene assemblage of the Coccolithus formosus Subzone (CP16b) including: Coccolithus eopelagicus, C. formosus, Dictyococcites bisectus, Discoaster tanii, Helicosphaera compacta, Isthmolithus recurvus, Reticulofenestra umbilica, Sphenolithus predistentus, S. pseudoradians, and Zygrhablithus bijugatus. C. formosus extends up to Sample $558-26-3,81-82 \mathrm{~cm}(399 \mathrm{~m})$ but is missing in the next higher Sample 558-26-1, 81-82 cm (396 m), which is assigned to the Sphenolithus predistentus Zone (CP17) because of the absence of $R$. umbilica and $R$. hillae, except for two reworked fragments. Therefore, the Reticulofenestra hillae Subzone is brief, if present, in the upper part of Core 558-26. Sphenolithus distentus occurs in Core 558-24 without $S$. ciperoensis, indicating the Sphenolithus distentus Zone (CP18). Cyclicargolithus floridanus is very abundant in both CP17 and CP18. The first $S$. ciperoensis, Discolithina segmenta, and $C y$ clicargolithus abisectus occur in Sample 558-23-5, 90-91 $\mathrm{cm}(374 \mathrm{~m})$, where Discoaster deflandrei is the sole discoaster following the disappearance of $D$. tanii and then $D$. nodifer in Zone CP18. A conjunction of S. cipero- 
Table 1. Cenozoic coccolith zonation of core samples from Leg 82 holes.

\begin{tabular}{|c|c|c|c|c|c|c|c|c|c|}
\hline Age & & Zone & & Subzone & 558 & $558 \mathrm{~A}$ & 563 & 560 & 564 \\
\hline \multirow{5}{*}{ Quaternary } & $\mathrm{CN} 15$ & \multicolumn{3}{|l|}{ Emiliania huxleyi } & & \multirow{2}{*}{$1-1 / 2-1 \quad 2-3 / 2-5$} & & & \\
\hline & \multirow{2}{*}{$\mathrm{CN} 14$} & \multirow{2}{*}{$\begin{array}{c}\text { Gephyrocapsa } \\
\text { oceanica }\end{array}$} & $\mathrm{CN} 14 \mathrm{~b}$ & Ceratolithus cristatus & & & & & \\
\hline & & & CN14a & Emiliania ovata & & $3-1 / 5-1$ & & & \\
\hline & \multirow{2}{*}{$\mathrm{CN} 13$} & \multirow{2}{*}{$\begin{array}{l}\text { Crenalithus } \\
\quad \text { doronicoides }\end{array}$} & $\mathrm{CN} 13 \mathrm{~b}$ & Gephyrocapsa caribbeanica & & $5-3 / 7-1$ & & & \\
\hline & & & CN13a & Emiliania annula & & & & & \\
\hline \multirow{9}{*}{ Pliocene } & \multirow{4}{*}{$\mathrm{CN} 12$} & \multirow{4}{*}{$\begin{array}{l}\text { Discoaster } \\
\text { brouweri }\end{array}$} & CN12d & Discoaster triradiatus & & $7-3 / 7-5$ & & & \\
\hline & & & $\mathrm{CN} 12 \mathrm{c}$ & Discoaster pentaradiatus & & & & & \\
\hline & & & $\mathrm{CN} 12 \mathrm{~b}$ & Discoaster surculus & & $8-1 / 9-1$ & & & \\
\hline & & & CN12a & Discoaster tamalis & & $9-3$ & & & \\
\hline & \multirow{2}{*}{ CN11 } & \multirow{2}{*}{$\begin{array}{l}\text { Reticulofenestra } \\
\text { pseudoumbilica }\end{array}$} & CNIIb & Discoaster asymmetricus & & & & & \\
\hline & & & CN11a & Sphenolithus neoabies & & & & & \\
\hline & \multirow{3}{*}{ CN10 } & \multirow{3}{*}{$\begin{array}{l}\text { Amaurolithus } \\
\text { tricorniculatus }\end{array}$} & CN10d & Amaurolithus delicatus & & & & & \\
\hline & & & $\begin{array}{l}\text { CN10c } \\
\text { CN10b }\end{array}$ & $\begin{array}{l}\text { Ceratolithus rugosus } \\
\text { Ceratolithus acutus }\end{array}$ & & & & & \\
\hline & & & CN10a & Triquetrorhabdulus rugosus & & & & & \\
\hline \multirow{13}{*}{ Miocene } & \multirow{2}{*}{ CN9 } & \multirow{2}{*}{$\begin{array}{l}\text { Discoaster } \\
\text { quinqueramus }\end{array}$} & $\mathrm{CN} 9 \mathrm{~b}$ & Amaurolithus primus & & $10-1 / 15-3$ & & & \\
\hline & & & CN9a & Discoaster berggrenii & & $15-5 / 16-5$ & & & \\
\hline & \multirow[t]{2}{*}{ CN8 } & \multirow{2}{*}{$\begin{array}{l}\text { Discoaster } \\
\text { neohamatus }\end{array}$} & $\mathrm{CN} 8 \mathrm{~b}$ & Discoaster neorectus & & & & & \\
\hline & & & CN8a & Discoaster bellus & $1-1 / 2-5$ & & $1-1 / 2-5$ & & \\
\hline & \multirow{2}{*}{$\mathrm{CN} 7$} & \multirow{2}{*}{$\begin{array}{l}\text { Discoaster } \\
\text { hamatus }\end{array}$} & CN7b & Catinaster calyculus & $3-1 / 3-5$ & & $2-7 / 3-5$ & & \\
\hline & & & CN7a & Helicosphaera carteri & $4-1$ & & & & \\
\hline & CN6 & Catinaster coalitus & & & $4-3 / 6-5$ & & $4-3 / 6-1$ & & \\
\hline & CN5 & $\begin{array}{c}\text { Discoaster } \\
\text { exilis }\end{array}$ & CN5b & Discoaster kugleri & $7-1$ & & & & \\
\hline & & exilis & CNSa & Coccolithus miopelagicus & $8-1 / 12-3$ & & $6-3 / 8-5$ & & \\
\hline & $\begin{array}{l}\mathrm{CN} 4 \\
\mathrm{CN} 3\end{array}$ & $\begin{array}{l}\text { Sphenolithus heteron } \\
\text { Helicosphaera ampli }\end{array}$ & norphus & & $\frac{13-1 / 15-3}{16-1 / 16-3} 15-5$ & & $\begin{array}{r}9-1 / 11-3 \\
12-1 / 13-1\end{array}$ & $1-1$ & \\
\hline & $\mathrm{CN} 2$ & Sphenolithus belemn & & & $16-5 / 17-1$ & & $\frac{12-1 / 13-1}{13-2 / 14-6}$ & & \\
\hline & & Triquetrorhabdulus & CNIc & Discoaster druggii & $17-2 / 18-2$ & & $14-7 / 15-5$ & & \\
\hline & CN1 & carinatus & CNIb & Discoaster deflandrei & $18-3 / 19-1$ & & $15-6 / 16-1] 16-3 / 16-5$ & & \\
\hline & & & $\mathrm{CN} 1 \mathrm{a}$ & Cyclicargolithus abisectus & $19-3$ & & & & \\
\hline & CP19 & $\begin{array}{l}\text { Sphenolithus } \\
\text { ciperoensis }\end{array}$ & CP19b & Dictyococcites bisectus & $19-5 / 21-3$ & & $16-7 / 18-5$ & & \\
\hline & & & CP19a & Cyclicargolithus floridamus & $22-1 / 23-5$ & & & & \\
\hline Oligocene - & CP17 & $\begin{array}{l}\text { Sphenolithus distent: } \\
\text { Sphenolithus prediste }\end{array}$ & & & $24-1 / 24-3$ & & $19-1$ & & HI-6 \\
\hline & & spnenominas preaisre & entus & & $25-1 / 26-1$ & & $19-3 / 21-7$ & & \\
\hline & CP16 & Helicosphaera & CP16c & Reticulofenestra hillae & & & $22-1$ & & $\mathrm{H} 1-7$ \\
\hline & & & CP160 & $\begin{array}{l}\text { Coccolithus formosus } \\
\text { Coccolithus subdistichus }\end{array}$ & $26-3 / 27-1$ & & $22-3$ & & \\
\hline & CP15 & $\begin{array}{l}\text { Discoaster } \\
\quad \text { barbadiensis }\end{array}$ & $\begin{array}{l}\text { CP15b } \\
\text { CP15a }\end{array}$ & $\begin{array}{l}\text { Isthmolithus recurvus } \\
\text { Chiasmolithus oamaruensis }\end{array}$ & & & & & \\
\hline & CP14 & $\begin{array}{c}\text { Reticulofenestra } \\
\text { umbilica }\end{array}$ & $\begin{array}{l}\text { CP14b } \\
\text { CP14a }\end{array}$ & $\begin{array}{l}\text { Discoaster saipanensis } \\
\text { Discoaster bifax }\end{array}$ & & & & & \\
\hline Eocene & CP13 & $\begin{array}{r}\text { Nannotetrina } \\
\text { quadrata }\end{array}$ & $\begin{array}{l}\text { CP13c } \\
\text { CP13b } \\
\text { CP13a }\end{array}$ & $\begin{array}{l}\text { Coccolithus staurion } \\
\text { Chiasmolithus gigas } \\
\text { Discoaster strictus }\end{array}$ & & & & & \\
\hline & CP12 & $\begin{array}{l}\text { Discoaster } \\
\quad \text { sublodoensis }\end{array}$ & $\begin{array}{l}\text { CP12b } \\
\text { CP12a }\end{array}$ & $\begin{array}{l}\text { Rhabdosphaera inflata } \\
\text { Discoasteroides kuepperi }\end{array}$ & & & & & \\
\hline & $\begin{array}{l}\text { CP11 } \\
\text { CP10 }\end{array}$ & $\begin{array}{l}\text { Discoaster lodoensis } \\
\text { Tribrachiatus orthost }\end{array}$ & & & & & & & \\
\hline & CP9 & $\begin{array}{l}\text { Discoaster } \\
\quad \text { diastypus }\end{array}$ & $\begin{array}{l}\text { CP9b } \\
\text { CP9a }\end{array}$ & $\begin{array}{l}\text { Discoaster binodosus } \\
\text { Tribrachiatus contortus }\end{array}$ & & & & & \\
\hline & CP8 & $\begin{array}{l}\text { Discoaster } \\
\quad \text { multiradiatus }\end{array}$ & $\begin{array}{l}\text { CP8b } \\
\text { CP8a }\end{array}$ & $\begin{array}{l}\text { Campylosphaera eodela } \\
\text { Chiasmolithus bidens }\end{array}$ & & & & & \\
\hline Paleocene - & $\begin{array}{l}\text { CP7 } \\
\text { CP6 } \\
\text { CP5 } \\
\text { CP4 } \\
\text { CP3 } \\
\text { CP2 }\end{array}$ & $\begin{array}{l}\text { Discoaster nobilis } \\
\text { Discoaster mohleri } \\
\text { Heliolithus kleinpelli } \\
\text { Fasciculithus tympan } \\
\text { Ellipsolithus macellu } \\
\text { Chiasmolithus danict }\end{array}$ & $\begin{array}{l}\text { i } \\
\text { iformis } \\
\text { us } \\
\end{array}$ & & & & & & \\
\hline & $\mathrm{CP} 1$ & $\begin{array}{l}\text { Zygodiscus } \\
\text { sigmoides }\end{array}$ & $\begin{array}{l}\text { CP1b } \\
\text { CP1a }\end{array}$ & $\begin{array}{l}\text { Cruciplacolithus tenuis } \\
\text { Cruciplacolithus primus }\end{array}$ & & & & & \\
\hline
\end{tabular}

Note: The numbers assigned to zonal intervals are core and section numbers of samples examined. Where a zone or subzone is represented in samples from two or more core sections, the highest and lowest are given, separated by a slash. The name of Subzone CN12d (Okada and Bukry, 1980) is renamed the Discoaster triradiatus Subzone to avoid duplication of names with the Calcidiscus macintyrei Zone of Gartner (1977). 
ensis with $S$. distentus signifies the upper Oligocene $C y$ clicargolithus floridanus Subzone (CP19a) in samples from Core 558-23 and lower Core 558-22. The uppermost sample of Core 558-22 is assigned to CP19a, but $S$. ciperoensis, which occurs above and below, was not identified there.

Assemblages from upper Oligocene and lower Miocene Zones CP19 and CN1 are characterized by abundant Cyclicargolithus floridanus, Discoaster deflandrei, and Sphenolithus. Triquetrorhabdulus carinatus occurs first in Subzone CP19b, Sample 558-20-1, 90-91 cm ( $339 \mathrm{~m}$ ), but is not common below Core 558-18. Sparse Sphenolithus delphix and S. capricornutus occur in lower Core 558-18, below the first occurrence of Discoaster druggii in Sample 558-18-2, 89-90 cm (322 m). The lowest Calcidiscus leptoporus occurs in Sample 558-18-5, $40-41 \mathrm{~cm}(326 \mathrm{~m})$, but Helicosphaera carteri (another auxiliary guide to basal Miocene assemblages) is not present. Minor reworking of Dictyococcites bisectus occurs in Sample 558-19-1, 90-91 cm (330 m) and Sample $558-18-5,40-41 \mathrm{~cm}$ (326 m).

Discoaster druggii is sparse in Cores 558-17 and 558-18 at Site DSDP 558. A gap in the range of D. druggii occurs midway through the Discoaster druggii Subzone (CN1c) in Samples 558-17-4, 90-91 cm (315 m) and $558-17-5$, 90-91 cm (317 m), dividing $D$. druggii occurrences into a lower and an upper range (Table 2). This two-part range for $D$. druggii has been previously demonstrated at DSDP sites in the Atlantic and Pacific (Bukry, 1976). The gap could record a minor global climatic pulse affecting plankton ecology. Barron and Keller (1982) also suggest a widespread sedimentary hiatus (NH 1a) at about this time. There is a slight reduction in coccolith diversity in the assemblages of the $D$. druggii Subzone gap at DSDP 558 and nearby DSDP 563.

The appearance of Sphenolithus belemnos s. str. (with a narrow, tall basal cycle and single apical spine) marks the base of the Sphenolithus belemnos Zone (CN2) in Sample 558-17-1, 90-91 cm (311 m). Zone CN2 is brief at Site DSDP 558, because $S$. heteromorphus, the guide to the top of the zone, is present in Sample 558-16-3, $90-91 \mathrm{~cm}(304 \mathrm{~m})$ just $7 \mathrm{~m}$ higher. This may be evidence for hiatus NH 1b of Barron and Keller (1982) that is associated with a shortened or missing $S$. belemnos Zone. Aside from the abrupt change in sphenoliths from $S$. dissimilis and $S$. belemnos to $S$. heteromorphus (regular and small), the assemblages in Sections 558-16-3 and 558-16-5 are very similar.

The lower boundary of the Sphenolithus heteromorphus Zone (CN4) is in Sample 558-15-3, 90-91 cm (295 $\mathrm{m})$, if the criterion of the appearance of Calcidiscus macintyrei is used. But just below, in Sample 558-15-5, 90$91 \mathrm{~cm}(298 \mathrm{~m})$, a substantial abundance of long-rayed discoasters could provide a secondary marker for the base of Zone CN4, as applied in the tropical Pacific (Bukry, 1971). Because of some uncertainty for the higher latitude situation of Site DSDP 558, the assemblage in Sample 558-15-3, 90-91 cm is shown straddling the boundary (Table 1). Assemblages of Zone CN4, such as that in Sample 558-15-1, 90-91 cm (292 m) with Calcidiscus macintyrei (elliptic tube), Coccolithus miopelagi- cus, C. pelagicus, Cyclicargolithus floridanus, Discoaster deflandrei, D. variabilis s. ampl., Helicosphaera granulata, and Sphenolithus heteromorphus are augmented, in higher assemblages, by the addition of Discoaster exilis and $D$. signus. D. signus, which can serve as an ecostratigraphic guide for slightly warmer assemblages (Bukry, 1981b), is identified in Cores 558-12 and 558-13 with abundant Coccolithus spp. At nearby Site DSDP 563 it occurs in Cores 563-8 and 563-9, in the same stratigraphic interval bracketing the top of the $S$. heteromorphus Zone (CN4) and the bottom of the Discoaster exilis Zone (CN5). Higher assemblages show increasing abundances of Reticulofenestra placoliths and fewer discoasters, which suggest a middle middle Miocene cooling. Distinctly temperate conditions are shown in Sample $558-6-5,90-91 \mathrm{~cm}(212 \mathrm{~m})$ by a lack of short-ranged marker species and the dominance of low-diversity coolwater assemblages characterized by Discoaster variabilis and by Reticulofenestra spp. (with closed and open central areas) upward through Core 558-4. These assemblages correlate to the coeval temperate Discoaster variabilis Zone of the Pacific Coast (Bukry, 1973a; 1981b; Crouch and Bukry, 1979). Only in the late middle Miocene or early late Miocene Catinaster calyculus Subzone of Sample 558-3-5, 90-91 cm (184 m) did typical lowlatitude taxa become re-established at Site 558. The coolwater middle Miocene assemblages at DSDP 558 correspond to Neogene hiatus NH 4 of Barron and Keller (1982). This supports their principle that widespread Neogene hiatuses represent cool-water events.

Coccolith assemblages in seven samples between Samples 558-4-3, 90-91 cm (190 m) and 558-6-5, 90-91 cm $(212 \mathrm{~m})$ are above the range of Cyclicargolithus floridanus and lack low-latitude guide species Discoaster $\mathrm{ku}$ gleri and Catinaster coalitus, which define zonal units $\mathrm{CN} 5 \mathrm{~b}$ and CN6. Coccolithus miopelagicus, which is extinct or sparse above the Catinaster coalitus Zone (CN6), occurs only in Core 558-6. Therefore, Cores 558-4 and 558-5 may be equivalent to the Discoaster hamatus Zone (CN7) of low-latitude sites.

Cores 558-3 and 558-4 have especially abundant $\mathrm{Cal}$ cidiscus macintyrei. Warm-water discoasters become more abundant from the top of Core 558-4, with Discoaster neohamatus, to Core 558-3, which contains the sparse Catinaster calyculus and Discoaster hamatus that define the Catinaster calyculus Subzone (CN7b).

The overlying upper Miocene Discoaster bellus Subzone (CN8a) is characterized at Site DSDP 558 by Discoaster bellus, $D$. challengeri, $D$. neohamatus, $D$. prepentaradiatus, and $D$. variabilis in the lower part of the subzone in Core 558-2. However, higher Core 558-1 has the lowest occurrence surface (LOS) of $D$. pentaradiatus, D. brouweri s. ampl. is more common, and D. challengeri is much rarer. Together with sparse specimens of Discoaster blackstockae and D. quadramus in Sample $558-1-3,34-35 \mathrm{~cm}(160 \mathrm{~m})$, this suggests a warming trend upward through the upper part of the subzone. There are no specimens of older $D$. calcaris or D. hamatus nor of younger $D$. loeblichii and $D$. neorectus in Cores 558-1 or 558-2. Other typical species for CN8a at DSDP 558, and elsewhere, include Helicosphaera granulata, 
Table 2. Occurrence checklist of selected lower Miocene coccoliths at Mid-Atlantic Ridge Sites DSDP 558 and 563 to illustrate the species matrix in the vicinity of the Discoaster druggii Subzone (CN1c) and Sphenolithus belemnos Zone (CN2).

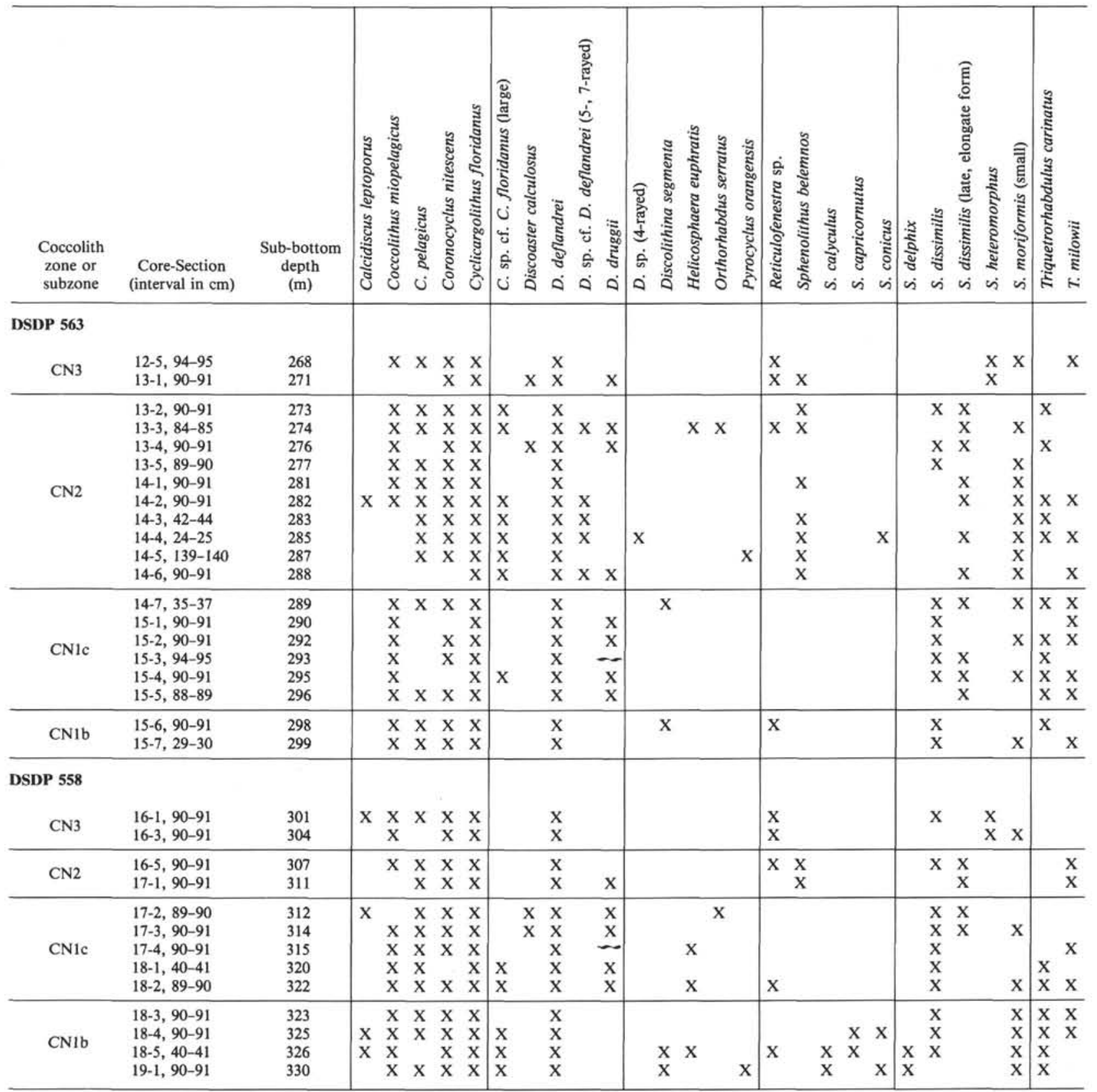

Note: The gap shown ( $\ldots$ ) in the range of Discoaster druggii has been noted in DSDP sections from other ocean basins.

Minylitha convallis, and Triquetrorhabdulus rugosus. Some warm-water taxa, such as Discoaster blackstockae, D. brouweri s. ampl., D. quadramus, and Discolithina sp., are recorded only in the upper part of Core 558-1. Overgrowth and etching are only slight. Typical placoliths in the subzone include Calcidiscus leptoporus, C. macintyrei, C. rotula, Coccolithus pelagicus, Reticulofenestra pseudoumbilica (closed and open centers), and $R$. spp. (small and medium).

The highest sample from the first hole at DSDP 558, Sample 558-1-1, 34-35 cm (158 m), contains an assemblage that appears to be well within Subzone CN8a and not near the boundary with the overlying Subzone CN8b.
Coring of a second hole (558A) at this site from the seafloor to $132 \mathrm{~m}$ failed to sample Subzone CN8b or upper Subzone CN8a because of the 36-m coring gap between the sections at Holes 558 and 558A.

The continuation of this section in the bottom of Hole $558 \mathrm{~A}$ is in a distinctly higher assemblage assigned to the Discoaster berggrenii Subzone (CN9a). Discoaster berggrenii, $D$. loeblichii, and $D$. surculus determine the higher correlation for basal Sample 558A-16-5, $90-91 \mathrm{~cm}(129 \mathrm{~m})$. Older taxa such as Discoaster neohamatus, D. neorectus, and Minylitha convallis persist. Warm conditions may be suggested by the high discoaster diversity and abundance of Coccolithus pelagicus 
relative to Reticulofenestra pseudoumbilica (Bukry, 1981c). A similar warming in the North Atlantic at about $8 \mathrm{Ma}$ was recorded by Haq (1980), but without the Coccolithus abundance relative to Reticulofenestra. The first Discoaster quinqueramus occurs above in Sample 558A-16-3, $90-91 \mathrm{~cm}(126 \mathrm{~m})$ and older Discoaster neohamatus Zone discoasters disappear shortly above this level.

Amaurolithus primus is missing from Sample 558A$15-5,90-91 \mathrm{~cm}(119 \mathrm{~m})$ but is present in Sample 558A$15-3,90-91 \mathrm{~cm}(116 \mathrm{~m})$, indicating that the base of the Amaurolithus primus Subzone (CN9b) occurs in the lower part of Core 558A-15. As is typical at other DSDP sites, $A$. amplificus appears just above, in Sample 558A$15-1,90-91 \mathrm{~cm}(113 \mathrm{~m})$. A thick section of Subzone CN9b extends through Sample 558A-10-1, 90-91 cm (75 m) yielding a sediment accumulation rate exceeding $29 \mathrm{~m} /$ Ma $(=41 \mathrm{~m} / 1.4 \mathrm{Ma})$. This relation in Hole $558 \mathrm{~A}$ is consistent with high sedimentation rates within the $A$. primus Subzone in the Indian Ocean (Vincent et al., 1980), Pacific Ocean (Keller, 1980; Keller and Barron, 1981), and Atlantic Ocean (Baldauf, in press).

Subzone CN9b assemblages range as high as Sample 558A-10-1, 90-91 cm (75 m) where A. primus, A. tricorniculatus, and Triquetrorhabdulus rugosus occur with $D$. quinqueramus, $D$. surculus, $D$. tridenus, and $D$. variabilis. Within the substantial thickness of Subzone CN9b (41 m), the absence of Sphenolithus and Triquetrorhabdulus and an increased abundance of Reticulofenestra suggest a cooling event in the interval of Samples 558A14-2, 90-91 cm (105 m), 558A-13-3, 90-91 cm (100 m), and 558A-12-5, 90-91 cm (93 m), through the middle of the zone.

Just above Core 558A-10, a $7-\mathrm{m}$ coring attempt for Core 558A- 9 retrieved only $4.8 \mathrm{~m}$. The missing $2.2 \mathrm{~m}$ (a void at the base of the core) represent $2.6 \mathrm{Ma}$ between upper Miocene Subzone CN9b at $75 \mathrm{~m}$ and upper Pliocene Subzone CN12a at $71 \mathrm{~m}$ in Sample 558A-9-3, 90-91 cm $(71 \mathrm{~m})$. A hiatus that eliminated lower Pliocene sediment at this site appears to be the likely cause of the temporal gap between Cores 558A-9 and 558A10 ; there is no change in the character of the pelagic foraminifer-rich and coccolith-rich sediment that would have occurred if sedimentary rates had slowed drastically.

The upper Pliocene assemblage of Sample 558A-9-3, $90-91 \mathrm{~cm}(71 \mathrm{~m})$ contains a typical array including $\mathrm{Cal}$ cidiscus macintyrei, Ceratolithus rugosus, Crenalithus doronicoides, Coccolithus pelagicus, Discoaster asymmetricus, D. brouweri, D. pentaradiatus, D. surculus, D. tamalis, Helicosphaera sellii, and Rhabdosphaera clavigera, but no Reticulofenestra pseudoumbilica. Overlying sediment, in Sample 558A-9-1, 133-134 cm (68 m), contains the next higher Discoaster surculus Subzone (CN12b) with a similar assemblage, but also including Ceratolithus separatus. The absence of discoasters $D$. asymmetricus and D. tamalis distinguish the two samples from Core 558A-9 as belonging to different subzones. C. separatus, with a saddle-shaped arch, was originally defined at Mid-Atlantic Ridge Site DSDP 396 in the Pliocene (Bukry, 1978a) in mixed-age assemblages. The occurrence at DSDP 558A confirms the upper Pliocene assignment for $C$. separatus that was inferred at
DSDP 396. This new occurrence also extends the latitudinal range for the species $15^{\circ}$ northward from latitude $23^{\circ} \mathrm{N}$ at DSDP 396 to latitude $38^{\circ} \mathrm{N}$ at DSDP 558 .

The Discoaster surculus Subzone (CN12b) occurs through Core $558 \mathrm{~A}-8$, but $D$. surculus is very sparse in Sample 558A-8-1, 100-101 cm (59 m), suggesting that the short Discoaster pentaradiatus Subzone (CN12c) may occur in the unsampled upper part of Section 558A-8-1. Discoaster assemblages in Core 7 are reduced to only $D$. brouweri in Sample 558A-7-5, 100-101 cm (55 m) and $D$. brouweri and D. triradiatus in Sample 558A-7-3, $100-101 \mathrm{~cm}(52 \mathrm{~m})$. Both samples belong to the uppermost Pliocene Discoaster triradiatus Subzone (CN12d) and are diverse and well-preserved with Ceratolithus, Discolithina, Helicosphaera, Rhabdosphaera, Scyphosphae$r a$, and Syracosphaera, in addition to the typical array of placoliths.

Lower Pleistocene assemblages in Cores 558A-5 to 558A-7 are typified by abundant Coccolithus pelagicus, Crenalithus productellus, common Discolithina japoni$c a$, Helicosphaera carteri, and sparser, but continuously present, Gephyrocapsa caribbeanica and Scyphosphae$\mathrm{ra}$. The last continuous Calcidiscus macintyrei, in Sample $558 \mathrm{~A}-7-1,100-101 \mathrm{~cm}(49 \mathrm{~m})$, has been dated at $1.51 \mathrm{Ma}$ (Gartner, 1977) and occurs in the Gephyrocapsa caribbeanica Subzone (CN13b). Helicosphaera sellii, which disappeared about 1.22 Ma (Gartner, 1977), occurs as high as Sample 558A-5-1, 90-91 cm (30 m) and Gephyrocapsa oceanica first occurs just above in Sample 558A-4-5, 90-91 cm (26 m), marking the base of the Gephyrocapsa oceanica Zone (CN14). Ceratolithus is missing in most Quaternary assemblages of DSDP $558 \mathrm{~A}$; sparse occurrences are noted only in Samples $558 \mathrm{~A}-1-1,53-54 \mathrm{~cm}(1 \mathrm{~m})$ and 558A-2-5, 90-91 cm $(7 \mathrm{~m})$. Previous coring along the Mid-Atlantic Ridge showed Ceratolithus to be sparse and sporadic north of latitude $35^{\circ} \mathrm{N}$ (Bukry, 1977).

The small placolith ooze of the middle Quaternary, about 0.9-1.2 Ma (Gartner, 1977), occurs in Sample $558 \mathrm{~A}-3-3,90-91 \mathrm{~cm}(14 \mathrm{~m})$. The conjunction of this coccolith assemblage with the Mesocena quadrangula acme (silicoflagellate) at lower latitudes (DSDP Leg 54; Bukry, 1980) suggests it should correlate to a general cooling (Bukry, 1983). The last Emiliania annula dated at about $0.46 \mathrm{Ma}$ (Thierstein et al., 1977) occurs in Sample 558A-3-1, 90-91 cm (11 m).

Reworking through the Quaternary is minor, and slight etching occurs in the well-preserved assemblages. Fluctuations in species dominance suggest that the Quaternary section at DSDP 558A should provide a good reference for paleoclimatic studies.

\section{Site 560 (lat. $34^{\circ} 43.33^{\prime} \mathrm{N}$, long. $38^{\circ} 50.56^{\prime} \mathrm{W}$; water depth, $3443 \mathrm{~m}$ )}

Site 560 is located on the west side of the Mid-Atlantic Ridge between the Oceanographer and Hayes fracture zones, on Magnetic Anomaly 5D. The sedimentary section from 0 to $373 \mathrm{~m}$ was washed instead of cored, in order to allow coring time to sample the igneous basement rocks. The single coccolith sample studied is from Core 560-1 and contains a lower middle Miocene Sphe- 
nolithus heteromorphus Zone (CN4) assemblage of coccoliths. Sample DSDP 560-1-1, 48-49 cm (373 m) contains guide species Calcidiscus macintyrei and $S$. heteromorphus, in addition to Coccolithus pelagicus, $C$. miopelagicus, Cyclicargolithus floridanus, Discoaster deflandrei, D. exilis, D. variabilis, and Helicosphaera granulata. The coccoliths in this basal assemblage are slightly older and less etched than those recovered at the base of the sediment section at Site DSDP 396 (CN5a) to the south. The basal assemblage at nearby Site DSDP 335 is younger still (CN5b) and better preserved (Bukry, 1977; 1978a).

\section{Site 563 (lat. $33^{\circ} 38.53$ ' $N$, Iong. $43^{\circ} 46.04^{\prime} \mathrm{W}$;} water depth, $3786 \mathrm{~m}$ )

Site DSDP 563 is located on the west side of the MidAtlantic Ridge about $100 \mathrm{~km}$ south of the Hayes Fracture Zone on Magnetic Anomaly 13 (approximately $37 \mathrm{Ma}$ ). The upper sedimentary section was not cored. Continuous coring for Cores 563-1 to 563-22, between 157 and $365 \mathrm{~m}$, recovered a coccolith zonal sequence from upper Miocene Subzone CN8a to lower Oligocene Subzone CP16b above basalt. Coccoliths are abundant but moderately to thickly overgrown throughout.

Lower Oligocene assemblages from Cores 563-20 to 563-22 (337 to $365 \mathrm{~m}$ ) are characterized by shallow-water taxa such as Braarudosphaera, Bramletteius, Peritrachelina, Vermiculithina, Zygrhablithus, and even rare Micrantholithus. The CP16b, CP16c, and CP17 biostratigraphic units are identified by primary boundary species Coccolithus formosus and Reticulofenestra hillae. The upper Zone CP17 assemblages in Samples 563-20-1, $50-51 \mathrm{~cm}(338 \mathrm{~m})$ and $563-19-3,38-39 \mathrm{~cm}(331 \mathrm{~m})$ lack all shallow indicators except Zygrhablithus. The upper Oligocene Sphenolithus distentus Zone is abbreviated, occurring only in Sample 563-19-1, 62-63 cm (328 m). The upper Oligocene Sphenolithus ciperoensis Zone, Dictyococcites bisectus Subzone (CP19b), occurs just above in Sample 563-18-5, 63-64 cm (325 m) and upwards to Sample 563-16-7, 31-32 cm (308 m), as identified by Sphenolithus ciperoensis with Cyclicargolithus abisectus and Triquetrorhabdulus spp. The Braarudosphaera-rich beds, which characterized the $S$. distentus Zone CP18 in the South Atlantic, do not occur at Site 563 and the CP19a Subzone and part of Zone CP18 may be missing at Site 563 .

There is no clear occurrence of the Cyclicargolithus abisectus Subzone (CN1a) in Core 563-16 (299 to $309 \mathrm{~m}$ ) at Site 563, owing to the scarcity of $C$. abisectus. The top of Core 563-16 and the base of Core 563-17 are assigned to Discoaster deflandrei Subzone (CN1b) because of the typical low diversity and great abundances of $C y$ clicargolithus floridanus, Discoaster deflandrei, and Sphenolithus moriformis.

Sample 563-15-5, 88-89 cm (296 m) contains the lower LOS of Discoaster druggii, which defines the base of Subzone CN1c. A discontinuity in the occurrence of $D$. druggii is noted in Sample 563-15-3, 94-95 cm (293 m) before the appearances of Sphenolithus belemnos and $S$. heteromorphus. At Site DSDP 558, this same gap and biostratigraphic sequence is recorded (Table 2). The gap in the range of $D$. druggii appears to be a general feature of the lower Miocene, being previously recorded at Sites DSDP 18, 238, 289, and 317 (Bukry, 1976). However, it might produce miscorrelation because $D$. druggii is needed to identify Subzone CN1c. The last common D. druggii coincides with the first Sphenolithus belemnos, and the first consistent large $C$. floridanus and five-rayed Discoaster deflandrei in Sample DSDP 563-14-6, 90-91 cm (288 m), suggesting an ecologic and sedimentary discontinuity from the underlying Sample $563-14-7,35-37 \mathrm{~cm}(289 \mathrm{~m})$. However, there is no obvious change in the sediment type between these samples. The large specimens of $C$. floridanus can be distinguished from $C$. abisectus by the pseudo-extinction gyres across the central area in cross-polarized light. Specimens of D. druggii in lower Core 563-13 are full-sized, but very sparse; at the top of Core 563-13 they are smaller.

A mixture of upper and lower Miocene assemblages occurs in Sample 563-13-1, 90-91 cm (271 m). The upper Miocene Amaurolithus primus Subzone (CN9b) is represented by Amaurolithus primus, A. delicatus, Discoaster brouweri, D. pentaradiatus, D. quinqueramus, $D$. surculus, and D. variabilis, whereas a lower Miocene contingent is characterized by Discoaster calculosus, $D$. deflandrei, D. druggii, Sphenolithus belemnos, and S. heteromorphus. There is no upper Miocene mixed with the Helicosphaera ampliaperta Zone (CN3) above in Core $563-12$, so the Core 563-13 mixture is likely to be a downhole contamination from slightly above the $157-\mathrm{m}$ level where coring was begun for this hole (compare nearby Hole DSDP 558A for the presence of $\mathrm{CN} 9 \mathrm{~b}$ in this area). Warm-water conditions for Zone CN3 are shown by the abundance of $D$. deflandrei and $S$. heteromorphus, with sparse Hayaster perplexus (Sample 563-12-3, $87-88 \mathrm{~cm}[265 \mathrm{~m}])$.

The LOS of Calcidiscus macintyrei in Sample 563-11-3, $90-91 \mathrm{~cm}(255 \mathrm{~m})$ and the diminished abundance of Discoaster deflandrei, in favor of longer-rayed discoasters, in Sample 563-11-1, 90-91 cm (252 m) characterize the base of the Sphenolithus heteromorphus Zone (CN4). Warm-water Discoaster signus occurs in several samples through the Zone CN4, but warm-water guides for higher zones are rare (Catinaster coalitus) or missing (Discoaster kugleri).

In the Discoaster hamatus Zone (CN7), Discoaster bellus and $D$. calcaris occur with $D$. hamatus, but warmwater $D$. neohamatus is missing. However, D. neohamatus is prominent in Sample 563-2-5, 90-91 cm $(173 \mathrm{~m})$ in the lower Discoaster neohamatus Zone (CN8) and upward to the top of the section with some variation. It is especially abundant in Sample 563-1-3, 90-91 cm (160 m), where Minylitha convallis is also abundant. Among the placoliths, Calcidiscus macintyrei and Reticulofenestra pseudoumbilica (closed-center and open-center forms of the same size) are abundant in Zone CN8. The coeval assemblage in Zone CN8 at nearby Site DSDP 558 shows the same species array and diversity.

\section{Site 564 (lat. $33^{\circ} 44.36^{\prime} \mathrm{N}$, long. $43^{\circ} 46.03^{\prime} \mathrm{W}$; water depth, $3820 \mathrm{~m}$ )}

Site DSDP 564 is located on the west side of the MidAtlantic Ridge about $100 \mathrm{~km}$ south of the Hayes Fracture Zone on Magnetic Anomaly 13 (approximately 
$36 \mathrm{Ma}$ ). Site 564 is only $10 \mathrm{~km}$ north of Site 563 . Sediments were largely bypassed in the coring program, which was designed to test geochemical and geothermal properties of the igneous basement rocks.

One sediment core, just above basalt, contains upper Oligocene Sphenolithus distentus Zone (CP18) in Sample DSDP 564-H1-6, 134-135 cm (composite 0 to $284 \mathrm{~m}$ ) and lower Oligocene Reticulofenestra hillae Subzone (CP16c) in Sample DSDP 564-H1-7, 42-43 cm (composite 0 to $284 \mathrm{~m}$ ). Shallow-water taxa are prominent in Section 564-H1-7, including Angulolithina arca, Braarudosphaera spp., Bramletteius serraculoides, Peritrachelina joidesa s. ampl., and Zygrhablithus bijugatus. This is an ecologic facies similar to that recovered at JOIDES drill sites on the Blake Plateau (Bukry, 1970; Gartner, 1971). The CP18 assemblage of Section 564H1-6 has abundant $Z$. bijugatus but lacks pentaliths and Peritrachelina. Therefore, the coeval (CP18) Oligocene Braarudosphaera bloom of the South Atlantic (Bukry, 1978b; 1981c) probably did not extend as far north as DSDP 564.

\section{OLIGOCENE AND MIOCENE COCCOLITH CORRELATION, SITES 558 AND 369}

Obtaining a mid-latitude Mid-Atlantic Ridge reference section for Oligocene calcareous microfossils on Leg 82 was one goal of the JOIDES Stratigraphic Correlations Panel (R. Z. Poore, written communication, 1981) because previous drilling had failed to recover this interval for biostratigraphic and biogeographic studies. Although the Oligocene reference site had been planned for Leg 49 , hurricanes and mechanical delays prevented such coring. On Leg 82 both Holes DSDP 558 and 563 recovered nearly complete calcareous sections from lower Oligocene to upper Miocene for the Mid-Atlantic Ridge. Coccolith floras are abundant, moderately diverse, and well-preserved, with slight to moderate overgrowth.

Previous North Atlantic drilling on Legs 1, 2, 4, 11, $12,39,41,43,47$, and 48 recovered partial Oligocene sections or nearly complete sections that were in coastal areas or at high or low latitudes. Therefore, the Oligocene floras for DSDP 558 and 563 provide new data on Mid-Atlantic correlations for mid-latitude.

The primary contrasts between high-latitude North Atlantic Oligocene floras from DSDP 112 and 116 of Leg 12 and low-latitude floras from DSDP 354 (Leg 39) are in diversity and abundance (Laughton, A. S., Berggren, W. A., et al., 1972; Supko, P. R., Perch-Nielsen, K., et al., 1977). High-latitude floras lack, or have only sparse, Discoaster, Helicosphaera, and Sphenolithus; placoliths predominate. Nevertheless, many different species of Helicosphaera and Sphenolithus occur through the low-latitude Oligocene sections.

DSDP 369 is a mid-latitude Oligocene reference (lat. $27^{\circ} \mathrm{N}$ ) that is located in a coastal upwelling zone off northwestern Africa, as indicated by the rich silicoflagellate assemblages through the Oligocene (Bukry, 1978c). For this reason, it provides a contrast in fertility to the more oligotrophic Site DSDP 558 on the Mid-Atlantic Ridge (lat. $37^{\circ} \mathrm{N}$ ). In Lower Oligocene Subzone CP16b, both sites contain sparse Isthmolithus recurvus and Chiasmolithus, indicating somewhat temperate conditions.
The flora of blue-water Site DSDP 558 is distinguished by the presence of Sphenolithus moriformis, S. pseudoradians, and Zygrhablithus bijugatus and the absence or scarceness of Discolithina, Helicosphaera, and Rhabdosphaera. The reverse is true for the coastal, presumably more turbid, waters at Site DSDP 369 . Neither site contains pentaliths. Comparison between these two floras suggests that Oligocene Helicosphaera, Rhabdosphae$r a$, and Discolithina preferred hemipelagic conditions. Etching of specimens is somewhat more intense at DSDP 369 , presumably the result of acidity associated with biogenic opal. This comparison also suggests a blue-water preference for Sphenolithus.

In the upper Oligocene Zones CP18 and CP19, the flora at DSDP 558 is distinguished from the coastal flora at DSDP 369A by more abundant Sphenolithus and much rarer Helicosphaera. Another striking difference is the high abundance of tiny placoliths and relatively small numbers of Cyclicargolithus floridanus at DSDP 369A. Genus Discoaster is slightly more abundant at bluewater Site DSDP 558, but overall coccolith diversity is lower, especially in the lack of Helicosphaera and Discolithina species, which occur at the shallow Hole DSDP $369 \mathrm{~A}$, even though the assemblage is more etched at DSDP 369A. Complete remobilization of tiny placoliths, Discolithina, and Helicosphaera into solution and subsequent redeposition as secondary calcite overgrowths on the remaining DSDP 558A specimens could account for some of the observed differences. But such a solution effect would not account for the greater abundance of Cyclicargolithus floridanus and Sphenolithus at DSDP 558 , which probably does suggest open-marine preference of these taxa for this interval.

The contrast in coccolith floras between DSDP 558 and DSDP 369A is less noticeable in the middle Miocene Discoaster exilis Zone (CN5) where the dominant placoliths and discoasters and other taxa are the same. The chief differences are in the greater abundance of Discolithina and Helicosphaera at DSDP 369A. This is probably an ecologic difference, because the species arrays and preservation are otherwise very similar. The continued restriction of Discolithina and Helicosphaera in the Oligocene and Miocene limits their biostratigraphic utility for correlation between ocean and coastal-water regimes.

Floras of the upper middle Miocene Catinaster calyculus Subzone (CN7b) are similar in character at DSDP 558 and 369A, but different for the upper Miocene Discoaster bellus Subzone (CN8a). The Subzone CN8a flora of DSDP Sample 558-2-3, 90-91 cm is characterized by abundant Calcidiscus macintyrei, abundant Reticulofenestra (large and medium), no tiny placoliths, and only rare Helicosphaera. The reverse is true at DSDP Sample 369A-3-3, 70-71 cm, which contains abundant Helicosphaera and tiny placoliths. Discoaster and Sphenolithus arrays are similar and permit correlation. But environmental distinction is shown by the differences in placolith abundances. The predominance of $C$. macintyrei and Reticulofenestra species with closed centers probably indicates cooler conditions at DSDP 558A, as indicated by the abundance of such Reticulofenestra at high latitude. 
The highest correlation for the upper Miocene Discoaster berggrenii Subzone (CN9a) between Sample 558A-16-5, 90-91 cm (129 m) and Sample 369-1-3, 70$71 \mathrm{~cm}(3 \mathrm{~m})$ is based on key species such as Discoaster berggrenii, $D$. loeblichii, and $D$. neorectus. Distinct differences in the species array between the two locations include the predominant placoliths, Coccolithus pelagicus and small Crenalithus taganus. At Hole DSDP 558A, Coccolithus pelagicus predominates over Crenalithus taganus 72 to 28 for a count of 100 , whereas at Hole DSDP 369 the reverse prevails with C. taganus outnumbering Coccolithus pelagicus by 64 to 36 for a count of 100. Reticulofenestra pseudoumbilica is sparse at both sites, but Calcidiscus macintyrei is more common at open-ocean Hole 558A. The Oligocene distinctions between these two sites are recalled by the greater abundance of genera Discolithina, Helicosphaera, and Rhabdosphaera at coastal DSDP 369. The fewer specimens of Helicosphaera of Hole 558A are also clearly more incised and etched away by dissolution than the excellently preserved specimens at DSDP 369. Again, preservation in clayey nannofossil marl (carbonate = $60 \%$ ) from the continental slope deposit of DSDP 369 is superior to the mid-ocean preservation in a nannofossil ooze (carbonate $=87 \%$ ) for coccolith taxa that are solution prone. Therefore, the potential for continued refinements in correlation accuracy for nearshore ocean deposits is high because of original diversity and better preservation in hemipelagic sediment (Gartner and Bukry, 1969).

The somewhat larger abundance of Sphenolithus at Site DSDP 369 suggests that the warm-water preference of the genus became more important than the openocean preference. Overlapping factors, such as preservation, temperature, and turbidity, can be distinguished by quantitative comparison between ocean sites representing different regional settings (see the data set initiated by Haq, 1980). Detailed quantitative studies comparing selected sites such as DSDP 558 can clarify controls on fossil coccolith distribution.

\section{OLIGOCENE PENTALITH FACIES AND MID-ATLANTIC DIAGENESIS}

The South Atlantic regional Braarudosphaera Chalk Province (Bukry, 1978b; 1981c) of the upper Oligocene Sphenolithus distentus Zone (CP18) is not represented at DSDP Leg 82 sites. Unlike the Sphenolithus distentus Zone chalks predominated by Braarudosphaera, the coeval sediment in Cores DSDP 558-24, DSDP 563-19, and DSDP 564-H1 lack Braarudosphaera, limiting the northward extent of the Braarudosphaera Chalk Province in mid-ocean waters.

Lower in the Oligocene, in the Helicosphaera reticulata Zone (CP16) and Sphenolithus predistentus Zone (CP17), assemblages are not predominated by pentaliths, but Cores 568-20 to 563-22 at DSDP 563 and Core 564$\mathrm{H} 1$ at DSDP 564 contain sparse to common pentaliths. This is typical of shallow-marine settings in more coastal areas at this time (Bukry, 1970; Bukry et al., 1971). Because there is no sedimentary evidence for a nearby landmass, the crustal block of DSDP 563 and 564 might have been shallower during the early Oligocene than that containing DSDP 558, north of the Hayes and Oceanographer fracture zones. The general state of preservation and overgrowth of coccoliths at DSDP 558, 563, and 564 is very similar, so post-depositional diagenetic differentiation of the assemblages to eliminate pentaliths at DSDP 558 could seem unlikely, except for the greater abundance of carbonate rhombs (dolomitic) and clay in the sediment of DSDP 558. A replacement of pentaliths by rhombs could be a fairly direct diagenetic exchange, fostered by pentalith dissolution susceptibility and by higher heat flow and pore-water circulation at DSDP 558. The alternative explanation of different ocean-current or water-mass conditions persisting over the sites in a non-oscillatory mode in such a small area for so long is unlikely; however, there are more cool-water Chiasmolithus at DSDP 558.

Although topographic or oceanographic changes are possible, the partition of pentaliths between DSDP 558 and DSDP 563 and 564 is attributed mainly to the effects of differing diagenesis on different crustal blocks.

\section{SILICOFLAGELLATE CORRELATION FOR DSDP 558A}

Upper Pleistocene silicoflagellates in Cores 558A-2 and 558A-3 (Table 3 ) have been compared to coeval assemblages of the Dictyocha aculeata Zone (Bukry, 1981a) from other DSDP sites in the Atlantic at DSDP 410 $\left(45^{\circ} \mathrm{N}\right), 334\left(37^{\circ} \mathrm{N}\right), 412\left(36^{\circ} \mathrm{N}\right), 397\left(27^{\circ} \mathrm{N}\right), 358\left(38^{\circ} \mathrm{S}\right)$, $328\left(38^{\circ} \mathrm{S}\right)$, and $331\left(50^{\circ} \mathrm{S}\right)$, and in the eastern Pacific at $425\left(1^{\circ} \mathrm{N}\right)$ and $427\left(8^{\circ} \mathrm{N}\right)$. Total diversity is lowest (three taxa) at high latitude; Dictyocha aculeata, D. stapedia stapedia, and Distephanus speculum speculum are the most cosmopolitan.

A comparison of the sequence of events between silicoflagellate and coccolith species shows a tendency for the extinction of Dictyocha lingii just before the $D$. aculeata Zone and for an acme of D. stapedia aspinosa at a later time, during deposition of $D$. aculeata Zone sediment. The $D$. lingii and $D$. stapedia aspinosa sequence occurs at DSDP 558A, 412, and 397 in the Atlantic and is indicated for DSDP 425 in the Pacific by the acme of D. stapedia aspinosa within the zone. At all four sites the D. stapedia aspinosa acme is associated with the $\mathrm{Ce}$ ratolithus cristatus Subzone of coccoliths. The top of $D$. lingii is associated with the Emiliania ovata Subzone of coccoliths at DSDP 412 and 558A, but not at DSDP 397, where it occurs in the uppermost Gephyrocapsa caribbeanica Subzone of coccoliths.

Although $D$. lingii may be used as a secondary guide fossil for the Mesocena quadrangula Zone (Dumitrică, 1973; Bukry, 1979), it disappeared slightly before Mesocena quadrangula at DSDP 397 . Therefore, the presence of $D$. lingii in Sample 558A-3-3, 90-91 cm (14 m) at a location near the northern range limit for M. quadrangula (Bukry, 1977) suggests that this sample might well belong to the upper $M$. quadrangula Zone, even without the primary guide species. Association with the coccolith $E$. ovata Zone supports such a correlation.

Sample 558A-2-3, 90-91 cm (4 m) contains a low-diversity assemblage, limited by dissolution because near- 
Table 3. Occurrence (in \%) of Pleistocene silicoflagellate taxa at DSDP 558A.

\begin{tabular}{|c|c|c|c|c|c|c|}
\hline Zone & & Dictyoch & aculeata & & $\begin{array}{l}\text { D. aculeata or } \\
\text { M. quadrangula }\end{array}$ & - \\
\hline Sub-bottom depth (m) & 1 & 4 & 7 & 11 & 14 & 17 \\
\hline $\begin{array}{l}\text { Hole-Core-Section } \\
\text { (interval in } \mathrm{cm} \text { ) }\end{array}$ & $\begin{array}{l}558 \mathrm{~A}-2-1 \\
90-91\end{array}$ & $\begin{array}{l}558 \mathrm{~A}-2-3 \\
90-91\end{array}$ & $\begin{array}{c}558 \mathrm{~A}-2-5 \\
90-91\end{array}$ & $\begin{array}{c}558 \mathrm{~A}-3-1 \\
90-91\end{array}$ & $\begin{array}{c}558 \mathrm{~A}-3-3 \\
90-91\end{array}$ & $\begin{array}{l}558 \mathrm{~A}-3-5 \\
90-91\end{array}$ \\
\hline $\begin{array}{l}\text { Dictyocha aculeata } \\
D \text {. sp. cf. D. aculeata } \\
D \text {. calida calida } \\
D \text {. calida ampliata } \\
D \text {. lingii }\end{array}$ & $\begin{array}{r}26 \\
1\end{array}$ & $\begin{array}{r}28 \\
3\end{array}$ & $\begin{array}{r}21 \\
4 \\
1 \\
2\end{array}$ & $\begin{array}{l}X \\
X \\
X\end{array}$ & $\begin{array}{l}2 \\
1 \\
3\end{array}$ & \\
\hline $\begin{array}{l}\text { D. perlaevis perlaevis } \\
\text { D. stapedia aspinosa } \\
\text { D. stapedia stapedia } \\
\text { D. subaculeata } \\
\text { D. spp. }\end{array}$ & $\begin{array}{r}5 \\
66 \\
2\end{array}$ & $\begin{array}{r}64 \\
4\end{array}$ & $\begin{array}{r}52 \\
11 \\
1 \\
4\end{array}$ & $\mathrm{x}$ & $\begin{array}{r}6 \\
1 \\
41 \\
8 \\
5\end{array}$ & \\
\hline $\begin{array}{l}\text { Distephanus floridus } \\
\text { D. speculum f. coronata } \\
\text { D. speculum minutus (coronatid) } \\
\text { D. speculum speculum }\end{array}$ & $<1$ & & $\begin{array}{r}1 \\
<1 \\
1 \\
3\end{array}$ & & 9 & \\
\hline Total specimens & 300 & 200 & 300 & 4 & 300 & 0 \\
\hline Relative paleotemperature value (Ts) & 100 & 100 & 96 & - & 90 & - \\
\hline
\end{tabular}

Note: Relative paleotemperature values calculated according to Bukry (1981d). X = occurrence too sparse for meaningful percent.

ly all of the silicoflagellates are ghostly thin and fragments of the large diatom Ethmodiscus rex are more common (Mikkelsen, 1977) than elsewhere in Cores 558A-2 and 558A-3. The generally small size of Dictyocha stapedia stapedia at DSDP 558A is typical for the Dictyocha aculeata Zone.

Samples from DSDP 558A that were processed in acid for silicoflagellates but found to be barren include: 558A-1-1, 53-54 cm (1 m); 558A-3-5, 90-91 cm (17 m); $558 \mathrm{~A}-4-1,90-91 \mathrm{~cm}(20 \mathrm{~m})$; 558A-4-3, $90-91 \mathrm{~cm}(24 \mathrm{~m})$; 558A-4-5, 90-91 cm (26 m); 558A-5-1, 90-91 cm (30 m); 558A-5-3, 90-91 cm (33 m); 558A-6-2, 90-91 cm (41 m); 558A-7-3, 100-101 cm (52 m); and 558A-9-1, 133-134 cm $(68 \mathrm{~m})$.

\section{CONCLUSION}

The great abundance of coccoliths in the OligoceneMiocene interval of DSDP 558 and 563, and the nearly complete sequence between Zones CP16 and CN8 at both sites provides the first middle Tertiary biostratigraphic reference for the northern Mid-Atlantic region. Although overgrowth of specimens is typically moderate, diversity is sufficiently high to permit detailed studies of the assemblages. This initial study has shown a significant thinning or removal of sediment in higher intervals. No lower Pliocene sediment was identified in the samples studied, reminiscent of the spotty occurrence of this interval for the nearby sites of DSDP Leg 37 (Bukry, 1977). Minor gaps in the upper Pliocene are also indicated for Hole DSDP 558A.

The dual sections for the Oligocene-Miocene at DSDP 558 and 563 contain most of the low-latitude zonal boundary species, such as Sphenolithus ciperoensis. But a coolwater event is indicated at both sites for the upper middle Miocene upper Discoaster exilis Zone to lower Discoaster hamatus Zone, also correlated with Neogene hiatus NH 4 (Barron and Keller, 1982). The predominance of cosmopolitan species such as Discoaster variabilis and Reticulofenestra pseudoumbilica in that interval is more typical of the temperate-water Discoaster variabilis Zone. This contrasts with the warm-water conditions suggested by the presence of Discoaster signus at the upper Sphenolithus heteromorphus to the lower Discoaster exilis Zone boundary interval. The lower Miocene gap in the range of zonal guide Discoaster druggii can be identified and correlated at both DSDP 558 and 563. The Oligocene assemblages at these sites are very similar except for the presence of pentaliths at DSDP 563 , attributed to more intense diagenesis at DSDP 558. The greater abundance of dolomitic rhombs at DSDP 558 may represent remobilized carbonate from formerly present pentaliths.

Silicoflagellates are present only in a short interval of the upper Quaternary at DSDP 558A. Although most of the section belongs to a warm-water facies of the Dictyocha aculeata Zone, the lowermost sample, containing Dictyocha lingii, may be equivalent to the underlying Mesocena quadrangula Zone of low latitude. The age of 0.70 to $0.89 \mathrm{Ma}$ (Saito and Burckle, 1977) for the top of that zone would be within the range of the associated coccolith upper Emiliana ovata Subzone (CN14a) in DSDP Sample 558A-3-3, 90-91 cm (14 m).

\section{SYSTEMATIC PALEONTOLOGY OF NEW TAXA}

Silicoflagellates

\section{Genus DISTEPHANUS Stöhr, 1880 \\ Distephanus floridus Bukry, n. sp. (Plate 1, Figs. 1-4)}

not Dictyocha octonaria Ehrenberg, 1844, p. 186, 201. Figured by Lemmermann, 1901, pl. 11, fig. 18, as Distephanus speculum var. octonarius (Ehrenb.) Joerg. 
not Distephanus octonarius, Hovasse, 1932, p. 455, figs. 3a-3c, fig. 4a. [Too elongate with thin apical ring.]

not Distephanus octonarius (Ehr.) Deflandre, 1932, p. 503, figs. 7-12. [Too axially elongate with elliptic apical rings.]

?Dictyocha octonaria Ehr., Deflandre, 1950 (in part), fig. 29? (not elongate figs. 30-41).

not Distephanus octonarius var. polyactis (Jörg.) Glezer, 1966, p. 273, pl. 21, figs. 7-8, and text fig. 21 (3). [Mistaken citation for Distephanus octonarius (Ehrenberg) var. polyactis (Ehrenberg) Jørgensen.]

Distephanus octonarius Deflandre, Ling, 1973, p. 752, pl. 2, figs. 5, 6. [Invalid basionym.]

Distephanus polyactis (Ehrenberg), Bukry, 1973b (in part), p. 864, pl. 1, figs. 9, 10.

Distephanus octonarius Deflandre, Ling, 1977, p. 207, pl. 2, fig. 11. [Invalid basionym.]

Description. Distephanus floridus has an eight- (rarely seven- or nine-) spined, regular, polygonal basal ring with equant axes. The spines are moderate to long and essentially coequal. Basal pikes may be present. The apical ring, like the basal ring, is polygonal and symmetric with no distinct elongation. Because of the large diameter of the apical ring and normal tube width, the ring appears continguous to the basal ring, seen in plan view.

Remarks. Distephanus floridus is distinguished from Distephanus polyactis (Ehrenberg) by more polygonal apical ring, slightly longer spines, consistent octagonal format, and a smaller size. Part of the distinction for Distephanus floridus involves establishing what the names Distephanus octonarius (Ehrenberg) and Octactis pulchra Schiller represent. I accept the Loeblich et al. (1968) validation for $D$. octonarius (Ehrenberg), which includes Lemmermann's (1901) illustration as the first figured specimen. The small and circular apical ring and short spines of $D$. octonarius (Ehrenberg) clearly distinguish it from D. floridus. Octactis pulchra Schiller has a delicate apical structure, axial elongation of the basal ring, and no basal pikes (see Poelchau, 1976). All these distinguish it from $D$. floridus.

Distephanus floridus may have been recorded as Dictyocha octonaria Ehrenberg in the past because of confusion over the nature of that species. The type specimen (see Loeblich et al., 1968), from the Holocene, has very short spines and a small, circular apical ring that can be easily distinguished from Distephanus floridus, which has moderate to long spines and a very large apical ring that is circular to polygonal. Deflandre (1950) illustrated a wide variety of modern octagonal specimens, all of which he considered variations of Dictyocha octonaria, but none of which has the short spines and small apical ring of the type specimen. Ling $(1973 ; 1977)$, apparently influenced by Deflandre's species concept, illustrated specimens of D. floridus as Distephanus octonarius Deflandre. As a basionym, Ling (1973) cites Deflandre, 1932 , p. 503 , but Deflandre $(1932$, p. 503) repeatedly cites "Distephanus octonarius (Ehr.) Defl." with varieties and synonyms. Therefore Deflandre (1932) never claimed authorship for the name octonarius, as indicated in Ling $(1973 ; 1977)$. As to the varietal names of Glezer (1966) discussed by Ling (1977), her specimen of Distephanus octonarius (Ehr.) Defl. var. polyactis (Jörg.) Glezer has nine short spines and a circular basal ring that distinguish it from $D$. floridus, which has a polygonal, basically eight-sided base and moderate to long spines. D. octonarius (Ehr.) Defl. var. cyrtoides (Haeck.) Glezer is irregular and typologically unrelated to $D$. floridus. The broad species group concept of Deflandre (1932) and Glezer (1966) seem less reproducible for purposes of biostratigraphic zonation than the typologic species concept of $D$. floridus.

The species Dictyocha octonaria Ehr. with the original figure by Lemmermann (1901) has been accepted as valid by Loeblich et al. (1968). There is no Distephanus octonarius Defl. The new species can be clearly distinguished from Distephanus octonarius (Ehr.) Defl. One of the wide-ringed specimens that Deflandre (1932) erroneously attributed to $D$. octonarius (Ehr.) Defl. may be assignable to the new species D. floridus. Ling's $(1973 ; 1977)$ illustrations referred to D. octonarius Defl. belong to $D$. floridus.

Finally, Distephanus speculum var. octonarius f. polyactis (Ehrenberg) Jørgensen is a valid transfer of Dictyocha polyactis Ehrenberg, according to Loeblich et al. (1968). Its uncorrected citation in Ling (1973) as Distephanus octonarius var. polyactis (Jørgensen) Glezer, attributed to Jousé, could be confusing because this misauthored variety was equated to misauthored Distephanus octonarius Deflandre in Ling (1973).
Occurrence. Distephanus floridus, previously reported as various taxa including Distephanus octonarius and D. polyactis, is characteristic of Quaternary assemblages at middle and high latitudes at such sites as DSDP $310,191,184$, and 173 in the North Pacific. It is missing from low-latitude coeval strata at such sites as DSDP 504, 425, 420,321 , and 157 . The highest occurrence surface (HOS) of D. floridus is used as the top for the Distephanus floridus Zone (née Distephanus octonarius Zone) by Ling (1973), an interval in the mid-Quaternary of the North Pacific.

Size. Maximum internal diameter, 16 to $25 \mu \mathrm{m}$ (holotype $18 \mu \mathrm{m}$ ).

Holotype. USNM 365401 (Pl. 1, Fig. 1).

Isotypes. USNM 365402 and 365403.

Type locality. North Atlantic, Mid-Atlantic Ridge, DSDP Sample $558-2-5,90-91 \mathrm{~cm}(174 \mathrm{~m})$.

\section{Coccoliths}

\section{Genus CYCLOLITHELLA Loeblich and Tappan, 1963}

\section{Cyclolithella? neoaprica Bukry, n. sp.} (Plate 1, Figs. 6-12)

Description. Cyclolithella? neoaprica has a medium-sized, circular basal shield and an elevated tube cycle. Both the basal and tube cycle have sinistrally inclined crystallites in apical view. The periphery of each cycle is serrate. The tube opening occupies about a third the diameter of the basal shield and the outer tube wall occupies about half that diameter. The basal shield is composed of 25 to 35 crystallites and the tube cycle of 18 to 22 crystallites, both structures are bright in crosspolarized light. Crystallites in the low-relief basal shield are more distinct in cross-polarized light.

Remarks. Cyclolithella? neoaprica is distinguished from Cyclolithella aprica by a thicker and taller tube cycle and a much smaller central tube opening. Viewed with a single polarizer, the tube cycle of $C$.? neoaprica shows much higher optic relief than the basal shield, aiding identification among other circular coccoliths, such as Coccolithus formosus. Cyclolithella aprica was originally described from the middle Eocene of the Pacific (Roth, 1973).

Occurrence. Cyclolithella? neoaprica occurs in the lower Oligocene Coccolithus formosus Subzone (CP16b) of DSDP 558, Core 558-27 and lower Core 558-26, from the North Atlantic. It is meager in Core 558-27 and very sparse in Core 558-26.

Size. Maximum diameter, 7 to $11 \mu \mathrm{m}$ (holotype $8 \mu \mathrm{m}$ ).

Holotype. USNM 365404 (Plate 1, Figs. 6, 7).

Isotypes. USNM 365405 and 365406.

Type locality. North Atlantic, Mid-Atlantic Ridge, DSDP Sample $558-27-1,90-91 \mathrm{~cm}(406 \mathrm{~m})$.

\section{Genus SPHENOLITHUS Deflandre, 1952 \\ Sphenolithus calyculus Bukry, n. sp. \\ (Plate 1, Figs. 13-19)}

Description. Sphenolithus calyculus is slender with an apical spine equal to or taller than the height of the multispined base. The distinctive characters seen in cross-polarized light include the multispined base acting as four segments. With the major axis aligned to a polarization direction, the upper two segments are as large as the lower two and the upper two form a calyx for the apical spine, which is dark at this orientation. With the major axis aligned at $45^{\circ}$ to the polarization direction, an X-shaped pattern occurs in the base and the apical spine is bright and continuous with the base.

Remarks. As indicated by the cross-polarized light image of the base, Sphenolithus calyculus is distinguished from $S$. belemnos by the much greater relative area occupied by the upper two segments, from $S$. ciperoensis by the crossing instead of separated pseudoextinction lines at $45^{\circ}$ orientation, and from $S$. conicus by the longer and narrower apical spine and small size. The two upper segments of $S$. calyculus are equal to or larger than the basal segments, distinguishing it from $S$. heteromorphus and $S$. belemnos. The top of these upper segments is angled, forming a calyx to the base of the apical spine that may appear to extend a little beyond the spine outline in cross-polarized light. Previous references to upper Oligocene or lowermost Miocene $S$. belemnos or $S$. heteromorphus may have been based on specimens of $S$. calyculus.

Occurrence. Sphenolithus calyculus is sparse to meager in upper Core 558-19 and lower Core 558-18 at DSDP 558 in samples assigned 
to the basal Miocene Discoaster deflandrei Subzone (CN1b). Larger specimens occur in Core 558-18.

Size. Maximum height, 5 to $9 \mu \mathrm{m}$ (holotype $5 \mu \mathrm{m}$ ).

Holotype. USNM 365407 (Plate 1, Figs. 13-15).

Isotypes. USNM 365408 and 365409.

Type locality. North Atlantic, Mid-Atlantic Ridge, DSDP Sample 558-19-1, 90-91 cm (330 m).

\section{COCCOLITH TAXA CITED IN THIS REPORT}

Amaurolithus amplificus (Bukry and Percival)

A. delicatus Gartner and Bukry

A. primus (Bukry and Percival)

Bramletteius serraculoides Gartner

Calcidiscus macintyrei (Bukry and Bramlette)

C. leptoporus (Murray and Blackman)

Catinaster calyculus Martini and Bramlette

C. coalitus Martini and Bramlette

Ceratolithus rugosus Bukry and Bramlette

C. separatus Bukry

Coccolithus eopelagicus (Bramlette and Riedel)

C. formosus (Kamptner)

C. miopelagicus Bukry

C. pelagicus (Wallich)

Coronocyclus nitescens (Kamptner)

Crenalithus doronicoides Black and Barnes

C. productellus Bukry

C. taganus (Fonseca)

Cyclicargolithus abisectus (Müller)

C. floridanus (Roth and Hay)

Dictyococcites bisectus (Hay, Mohler, and Wade)

Discoaster asymmetricus Gartner

D. bellus Bukry and Percival

$D$. berggrenii Bukry

D. blackstockae Bukry

D. brouweri Tan

D. calcaris Gartner

D. calculosus Bukry

D. challengeri Bramlette and Riedel

D. deflandrei Bramlette and Riedel

D. druggii Bramlette and Wilcoxon

D. exilis Martini and Bramlette

D. hamatus Martini and Bramlette

D. kugleri Martini and Bramlette

D. loeblichii Bukry

D. neohamatus Bukry and Bramlette

D. neorectus Bukry

D. nodifer (Bramlette and Riedel)

D. pentaradiatus Tan

D. prepentaradiatus Bukry and Percival

D. quadramus Bukry

D. quinqueramus Gartner

D. signus Bukry

D. surculus Martini and Bramlette

D. tamalis Kamptner

D. tanii Bramlette and Riedel

D. triradiatus Kamptner

D. variabilis Martini and Bramlette

Discolithina segmenta Bukry and Percival

Emiliania annula (Cohen)

Hayaster perplexus (Bramlette and Riedel)

Helicosphaera compacta Bramlette and Wilcoxon

H. euphratis $\mathrm{Haq}$

$H$. granulata (Bukry)

$H$. sellii (Bukry and Bramlette)

Isthmolithus recurvus Deflandre

Minylitha convallis Bukry

Orthorhabdus serratus Bramlette and Wilcoxon

Peritrachelina joidesa Bukry and Bramlette

Pyrocyclus orangensis (Bukry)

Reticulofenestra hillae Bukry and Percival

$R$. pseudoumbilica (Gartner)

R. umbilica (Levin)

Rhabdosphaera clavigera (Murray and Blackman)

Sphenolithus belemnos Bramlette and Wilcoxon
S. capricornutus Bukry

S. ciperoensis Bramlette and Wilcoxon

S. conicus Bukry

S. delphix Bukry

S. dissimilis Bukry and Bramlette

S. distentus (Martini)

S. heteromorphus Deflandre

$S$. moriformis (Brönnimann and Stradner)

$S$. predistentus Bramlette and Wilcoxon

S. pseudoradians Bramlette and Wilcoxon

Triquetrorhabdulus carinatus Martini

T. milowii Bukry

Zygrhablithus bijugatus Deflandre

\section{SILICOFLAGELLATE TAXA CITED IN THIS REPORT}

Dictyocha aculeata (Lemmermann)

D. calida ampliata Bukry

D. calida calida Poelchau

D. lingii Dumitrică

D. perlaevis perlaevis Frenguelli

D. stapedia aspinosa Bukry

D. stapedia stapedia Haeckel

D. subaculeata (Bukry)

Distephanus speculum f. coronata Schulz

D. speculum minutus Bachmann emend. Bukry

Mesocena quadrangula Ehrenberg ex Haeckel

\section{DIATOM TAXON CITED IN THIS REPORT}

Ethmodiscus rex (Rattray)

\section{ACKNOWLEDGMENTS}

I thank Gerta Keller and John A. Barron, U.S. Geological Survey, for helpful reviews of this paper. Slides were prepared by Diane L. Lander, U.S. Geological Survey, and additional samples for an investigation of lower Miocene species ranges were supplied by Amy Altman, Deep Sea Drilling Project. I also thank Paula Worstell, Deep Sea Drilling Project, and Richard Z. Poore, U.S. Geological Survey, for their assistance in obtaining the valuable stratigraphic reference sections at DSDP 558 and DSDP 563. The manuscript was ably typed and proofed by Dorothy L. Blackstock, U.S. Geological Survey.

\section{REFERENCES}

Baldauf, J. G., in press. Cenozoic diatom biostratigraphy and paleoceanography of the Rockall Plateau Region, North Atlantic, Deep Sea Drilling Project Leg 81. In Roberts, D. G., Schnitker, D., et al., Init. Repts. DSDP, 81: Washington (U.S. Govt. Printing Office).

Barron, J. A., and Keller, G., 1982. Widespread Miocene deep-sea hiatuses: coincidence with periods of global cooling. Geology, 10: 577-581.

Bukry, D., 1970. Coccolith age determinations Leg 2, Deep Sea Drilling Project. In Peterson, M. N. A., Edgar, N. T., et al., Init. Repts. DSDP, 2: Washington (U.S. Govt. Printing Office), 349-355.

1971. Coccolith stratigraphy Leg 7, Deep Sea Drilling Project. In Winterer, E. L., Riedel, W. R., et al., Init. Repts. DSDP, 7 , Pt. 2: Washington (U.S. Govt. Printing Office), 1513-1528. 1973a. Coccolith and silicoflagellate stratigraphy, Deep Sea Drilling Project Leg 18, eastern North Pacific. In Kulm, L. D., von Huene, R., et al., Init. Repts. DSDP, 18: Washington (U.S. Govt. Printing Office), 817-831.

1973b. Coccoliths and silicoflagellates from Deep Sea Drilling Project Leg 19, North Pacific Ocean and Bering Sea. In Creager, J. S., Scholl, D. W., et al., Init. Repts. DSDP, 19: Washington (U.S. Govt. Printing Office), 857-867.

1976. Coccolith stratigraphy of Manihiki Plateau, central Pacific, Deep Sea Drilling Project Site 317. In Schlanger, S. O., Jackson, E. D., et al., Init. Repts. DSDP, 33: Washington (U.S. Govt. Printing Office), 493-501.

1977. Coccolith and silicoflagellate stratigraphy, central North Atlantic Ocean, Deep Sea Drilling Project Leg 37. In Aumento, F., Melson, W. G., et al., Init. Repts. DSDP, 37: Washington (U.S. Govt. Printing Office), 917-927.

1978a. Neogene coccolith stratigraphy, Mid-Atlantic Ridge, Deep Sea Drilling Project, Leg 45. In Melson, W. G., Rabinowitz, 
P. D., et al., Init. Repts. DSDP, 45: Washington (U.S. Govt. Printing Office), 307-317.

, 1978b. Cenozoic silicoflagellate and coccolith stratigraphy, southeastern Atlantic Ocean, Deep Sea Drilling Project Leg 40. In Bolli, H. M., Ryan, W. B. F., et al., Init. Repts. DSDP, 40: Washington (U.S. Govt. Printing Office), 635-649.

1978c. Cenozoic coccolith and silicoflagellate stratigraphy, offshore northwest Africa, Deep Sea Drilling Project Leg 41. In Lancelot, Y., Seibold, E., et al., Init. Repts. DSDP, 41: Washington (U.S. Govt. Printing Office), 689-707.

,1979. Comments on opal phytoliths and stratigraphy of Neogene silicoflagellates and coccoliths at Deep Sea Drilling Project Site 397 off northwest Africa. In Luyendyk, B. P., Cann, J. R., et al., Init. Repts. DSDP, 49: Washington (U.S. Govt. Printing Office), 977-1009.

1980. Silicoflagellate biostratigraphy and paleoecology in the eastern equatorial Pacific, Deep Sea Drilling Project Leg 54. In Rosendahl, B. R., Hekinian, R., et al., Init. Repts. DSDP, 54: Washington (U.S. Govt. Printing Office), 545-573.

1981a. Synthesis of silicoflagellate stratigraphy for Maestrichtian to Quaternary marine sediment. Spec. Publ.-Soc. Econ. Paleontol. Mineral., 32:433-444.

1981b. Pacific Coast coccolith stratigraphy between Point Conception and Cabo Corrientes, Deep Sea Drilling Project Leg 63. In Yeats, R. S., Haq, B. U., et al., Init. Repts. DSDP, 63: Washington (U.S. Govt. Printing Office), 445-471. 1981c. Cenozoic coccoliths from the Deep Sea Drilling Project. Spec. Publ.-Soc. Econ. Paleontol. Mineral., 32:335-353. , 1981d. Silicoflagellate stratigraphy of offshore California and Baja California, Deep Sea Drilling Project Leg 63. In Yeats, R. S., Haq, B. U., et al., Init. Repts. DSDP, 63: Washington (U.S. Govt. Printing Office), 539-557.

1983. Upper Cenozoic silicoflagellates from offshore Ecuador, Deep Sea Drilling Project Site 504. In Cann, J. R., Langseth, M. G., Honnorez, J., Von Herzen, R. P., White, S. M., et al., Init. Repts. DSDP, 69: Washington (U.S. Govt. Printing Office), 321-342.

Bukry, D., Douglas, R. G., Kling, S. A., and Krasheninnikov, V., 1971. Planktonic microfossil biostratigraphy of the northwestern Pacific area. In Fischer, A. F., Heezen, B. C., et al., Init. Repts. DSDP, 6: Washington (U.S. Govt. Printing Office), 1253-1300.

Crouch, J. K., and Bukry, D., 1979. Comparison of Miocene provincial foraminiferal stages to coccolith zones in the California Continental Borderland. Geology, 7:211-215.

Deflandre, G., 1932. Sur la systématique des silicoflagellés. Bull. Soc. Bot. Fr., 79:494-506.

1950. Contribution a l'étude des silicoflagellidés actuels et fossiles. Microscopie, 2:72-108, 117-142, and 191-210.

Dumitrică, P., 1973. Cretaceous and Quaternary radiolaria in deep sea sediments from the northwest [sic northeast] Atlantic Ocean and Mediterranean Sea. In Ryan, W. B. F., Hsü, K. J., et al., Init. Repts. DSDP, 13, Pt. 2: Washington (U.S. Govt. Printing Office), 829-901.

Ehrenberg, C. G., 1844. Resultate seiner Untersuchungen der ihm von der Südpolreise des Capitain Ross, so wie von den Herren Schayer und Darwin zugekommenen Materialien über das Verhalten des kleinsten Lebens in den Oceanen und den grössten bisher zugänglichen Tiefen des Weltmeers vor. Abh. K. Preuss. Akad. Wiss. Berlin Ber., Jahrg. 1844:182-207.

Gartner, S., Jr., 1971. Calcareous nannofossils from the Joides Blake Plateau cores and revision of Paleogene nannofossil zonation. Tulane Stud. Geol. Paleontol., 8:101-121.
1977. Calcareous nannofossil biostratigraphy and revised zonation of the Pleistocene. Mar. Micropaleontol., 2:1-25.

Gartner, S., Jr., and Bukry, D., 1969. Tertiary holococcoliths, J. Paleontol., 43:1213-1221.

Glezer, Z. I., 1966. Silicoflagellatophyceae. In Gollerbakh, M. M., (Ed.), Cryptogamic Plants of the U.S.S.R. (Vol. 7): Akad. Nauk SSSR, V. A. Komarova Bot. Inst. (Moskva-Leningrad) (Translated from Russian by Israel Program for Scientific Translations Ltd., Jerusalem, 1970)

Haq, B. U., 1980. Miocene biogeographic history of calcareous nannoplankton and paleoceanography of the Atlantic Ocean. Micropaleontology, 26:414-443.

Hovasse, R., 1932. Contribution a l'étude des silicoflagellés. Multiplication, variabilité, hérédité, affinités. Bull. Biol. Fr. Belg., 66: 447-501.

Keller, G., 1980. Middle to late Miocene planktonic foraminiferal datum levels and paleoceanography of the North and southeastern Pacific Ocean. Mar. Micropaleontol., 5:249-281.

Keller, G., and Barron, J. A., 1981. Integrated planktic foraminiferal and diatom biochronology for the northeast Pacific and the Monterey Formation. In Garrison, R. E., Douglas, R. G., Pisciotto, K. E., Isaacs, C. M., and Ingle, J. C. (Eds.), The Monterey formation and related siliceous rocks of California. Spec. Publ.-Soc. Econ. Paleontol. Mineral. Pacific Sec., 43-54.

Laughton, A. S., Berggren, W. A., et al., 1972. Init. Repts. DSDP, 12: Washington (U.S. Govt. Printing Office).

Lemmermann, E., 1901. Silicoflagellatae. Dtsch. Bot. Ges. Ber., 19: 247-271.

Ling, H. Y., 1973. Silicoflagellates and ebridians from Leg 19. In Creager, J. S., Scholl, D. W., et al., Init. Repts. DSDP, 19: Washington (U.S. Govt. Printing Office), 751-775.

1977. Late Cenozoic silicoflagellates and ebridians from the eastern North Pacific region. Proc. First Int. Cong. Pacific Neogene Stratigraphy, Tokyo, pp. 205-233.

Loeblich, A. R., III, Loeblich, L. A., Tappan, H., and Loeblich, A. R., Jr., 1968. Annotated index of fossil and recent silicoflagellates and ebridians with descriptions and illustrations of validly proposed taxa. Geol. Soc. Am. Mem., 106:1-319.

Mikkelsen, N., 1977. On the origin of Ethmodiscus ooze. Mar. Micropaleontol., 2:35-46.

Okada, H., and Bukry, D., 1980. Supplementary modification and introduction of code numbers to the low-latitude coccolith biostratigraphic zonation (Bukry, 1973; 1975). Mar. Micropaleontol., 5: 321-325.

Poelchau, H. S., 1976. Distribution of Holocene silicoflagellates in North Pacific sediments. Micropaleontology, 22:164-193.

Roth, P. H., 1973. Calcareous nannofossils-Leg 17, Deep Sea Drilling Project. In Winterer, E. L., Ewing, J. I., et al., Init. Repts. DSDP, 17: Washington (U.S. Govt. Printing Office), 675-795.

Saito, T., and Burckle, L. H., 1977. Occurrence of silicoflagellate Mesocena elliptica. J. Geol. Soc. Jpn., 83:181-186.

Supko, P. R., Perch-Nielsen, K., et al., 1977. Init. Repts. DSDP, 39: Washington (U.S. Govt. Printing Office).

Thierstein, H. R., Geitzenauer, K. R., Molfino, B., and Shackleton, N. J., 1977. Global synchroneity of late Quaternary coccolith datum levels: validation by oxygen isotopes. Geology, 5:400-404.

Vincent, E., Killingley, J. S., and Berger, W. H., 1980. The Magnetic Epoch-6 carbon shift: a change in the ocean's ${ }^{13} \mathrm{C} /{ }^{12} \mathrm{C}$ ratio 6.2 million years ago. Mar. Micropaleontol., 5:185-203.

Date of Initial Receipt: 7 June 1983

Date of Acceptance: 14 May 1984 

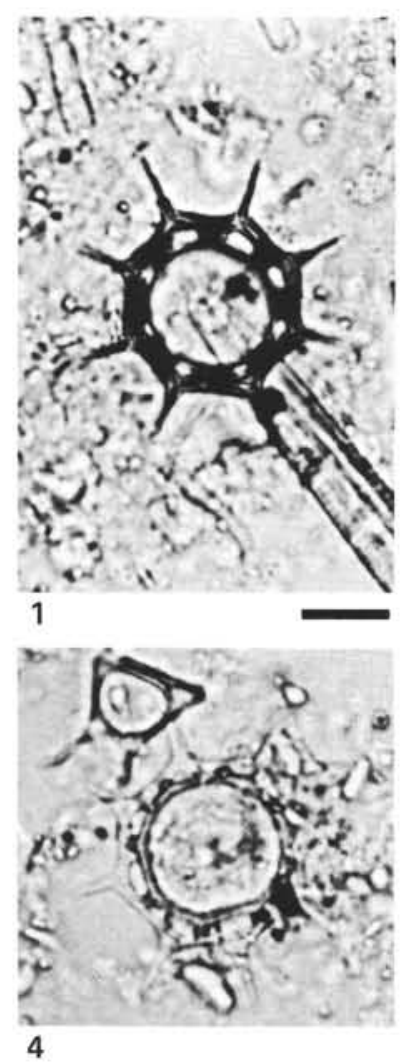
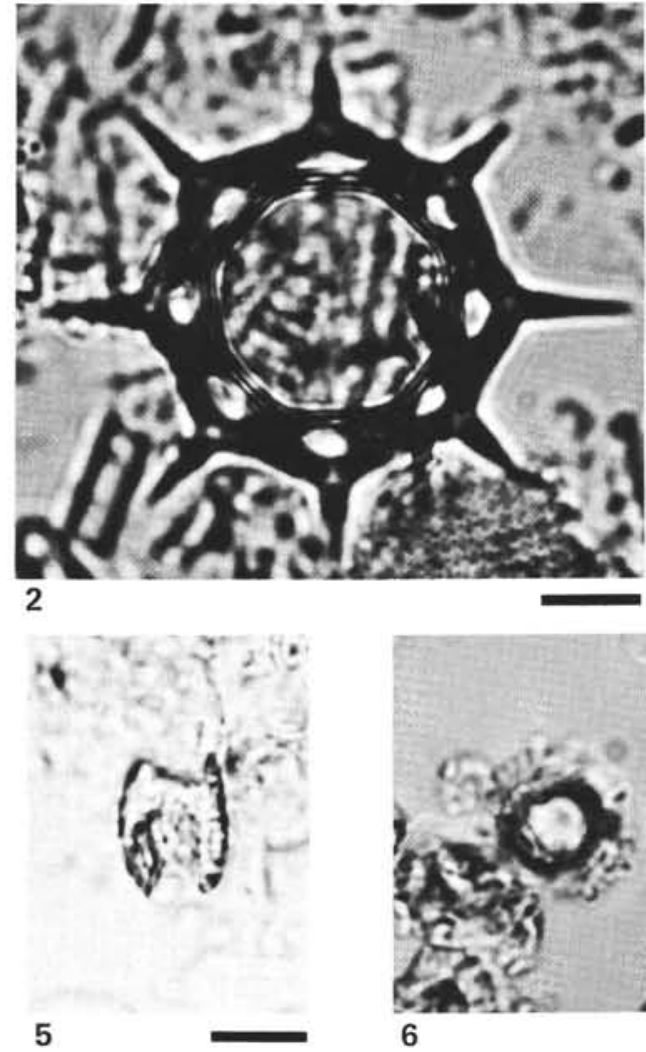

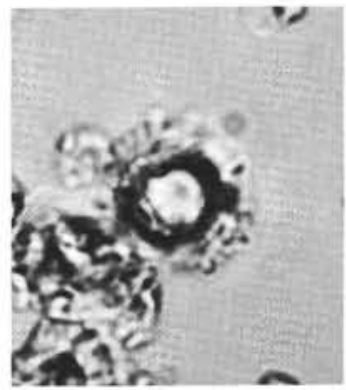

6

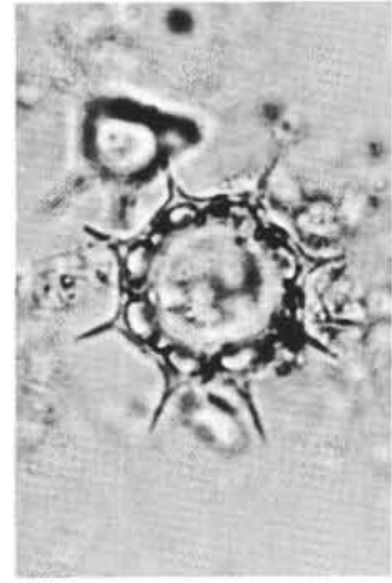

3

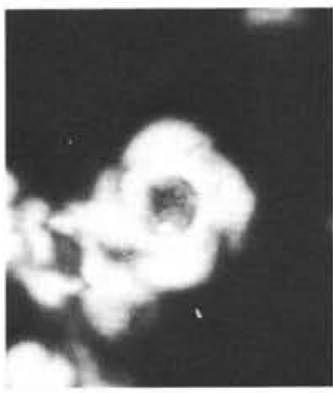

7

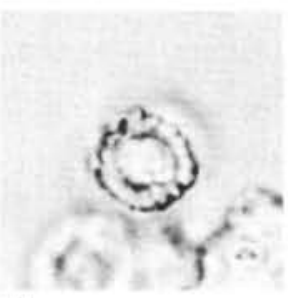

8

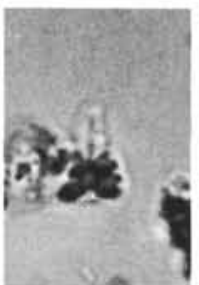

13

14

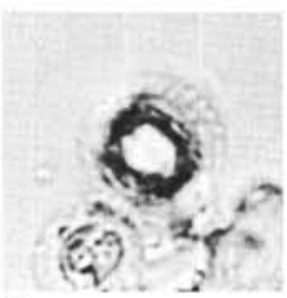

9

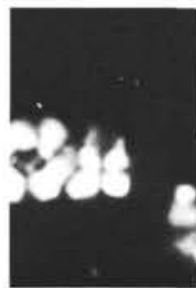

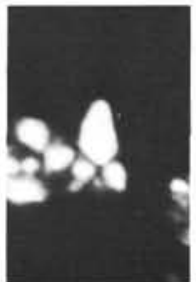

15

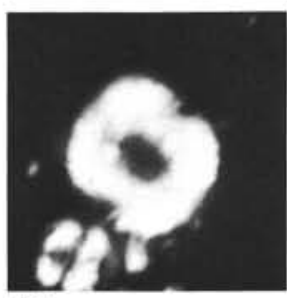

10

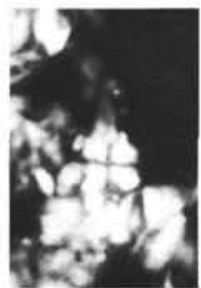

16

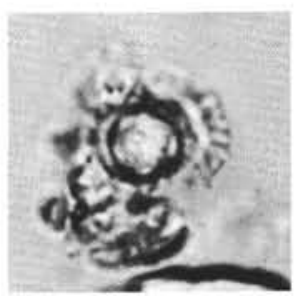

11

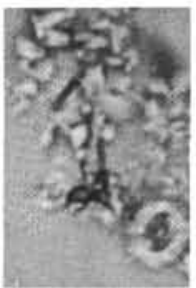

17

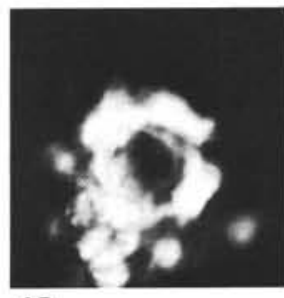

12

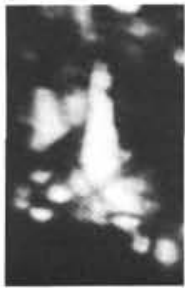

19

Plate 1. Cenozoic coccoliths and silicoflagellates from Sites DSDP 563, 558, and 190. Figures 1, 3, 4 magnified $900 \times$, scale bar equals $10 \mu \mathrm{m}$. Figures 2, 5-16, 18, 19 magnified $1900 \times$, scale bar equals $5 \mu \mathrm{m}$. Figure 17 magnified $1500 \times$, scale bar equals $10 \mu \mathrm{m}$. 1-4. Distephanus floridus Bukry, n. sp. (1) Holotype, USNM 365401, Sample 558A-2-5, 90-91 cm. (2) USNM 365402, Sample 190-4-1, 70-71 cm. (3, 4) USNM 365403 , high and low focus, Sample 558A-2-5, 90-91 cm. 5. Ceratolithus separatus Bukry, Sample 558A-9-1, 133-134. 6-12. Cyclolithella? neoaprica Bukry, n. sp. All specimens from Sample 558-27-1, 90-91 cm. $(6,7)$ USNM 365405, single-polarized (SP) and cross-polarized (XP) views. (8-10) Holotype, USNM 365404, SP high focus on tube cycle, SP low focus on shield, and XP; smaller Coccolithus pelagicus (Wallich) s. ampl. at left. (11, 12) USNM 365406, SP and XP. 13-19. Sphenolithus calyculus Bukry, n. sp. (13-15) Holotype, USNM 365407, Sample 558-19-1, 90-91 cm, SP $\left(0^{\circ}\right)$, XP $\left(0^{\circ}\right)$, XP $\left(45^{\circ}\right)$; Cyclicargolithus floridanus (Roth et Hay) at left. (16) USNM 365408, Sample 558-19-1, 90-91 cm, XP $\left(0^{\circ}\right)$. (17-19) USNM 365409, Sample 558-18-5, $40-41 \mathrm{~cm}$, SP $\left(45^{\circ}\right)$, SP $\left(0^{\circ}\right)$, XP $\left(45^{\circ}\right)$. 